\title{
Teologia dogmática e experiência espiritual cristã: Repensando a relação com H.U. von Balthasar
}

\author{
Dogmatic theology and Christian spiritual experience: rethinking the \\ relationship with $\mathrm{H}$. U. von Balthasar
}

Maria Abrão*

\begin{abstract}
Resumo
Ao propor a reflexão sobre as relações entre teologia dogmática e experiência espiritual cristã, queremos mostrar neste artigo como um grande teólogo do século XX, Hans Urs von Balthasar, convida o leitor a entrar na leitura e na compreensão das razões histórico-teológicas que orientaram algumas opções e posturas assumidas, bem como a reconhecer os impactos provocados tanto na teologia como na experiência espiritual, e ainda, mais amplamente, no cristianismo e na sua missão. O caminho escolhido para este estudo parte de uma de suas obras, L'amour seul est digne de foi, e apoia-se, a seguir, no impressionante acervo intelectual do autor, nele pesquisando a transversalidade do tema. No presente trabalho, à escuta da ameaça de rupturas, analisaremos, sobretudo, a concepção e a possibilidade da experiência espiritual cristã indagando o AT, o NT e os Santos Padres. Que esperança se delineia nesta interlocução? Poder-se-á depreender do percurso realizado conclusões parciais. Aprofundamentos ulteriores serão indispensáveis para chegar à compreensão de tudo o que está em jogo na busca de inteligibilidade da teologia e da própria experiência cristã.
\end{abstract}

Palavras-chave: Teologia; cristianismo; experiência espiritual; fé; dogmática; Balthasar.

\begin{abstract}
In proposing this reflection about the relationship between dogmatic theology and Christian spiritual experience, we want to demonstrate in this article how a great $20^{\text {th }}$ century theologian, Hans Urs von Balthasar, invites the reader to enter into the reading and understanding of the historical and theological reasons that have guided some options and postures assumed, as well as to recognize the impacts caused both in the theology and in the spiritual experience and yet, more widely, in Christianity and its mission. The path chosen for this study starts from one of his works, L'amour seul est digne de foi, and relies, then, in the impressive intellectual patrimony of the author, by researching in the same the transversality of the theme. We will be, in the present work, vigilant to the threat of disruptions, particularly analyze the conception and the possibility of the Christian spiritual experience by inquiring the Old Testament, the New Testament and the Holy Fathers. What is the hope delineated in this dialogue? It will be possible to infer partial conclusions from the route made. Further researches will be essential in order to reach the understanding of everything that is at stake in the search for intelligibility of the Theology and of the Christian experience itself.
\end{abstract}

Keywords: Theology; Christianity; spiritual experience; faith; dogmatic; Balthasar.

Artigo recebido em 29 de março de 2016 e aprovado em 27 de agosto de 2016.

* Doutorado em Teologia por Facultés Jésuites Centre Sèvres, Paris. Professora do Mestrado de Teologia da Universidade Católica de Pernambuco. Tem experiência na área de Teologia e trabalhou no Instituto Humanitas da UNICAP. País de Origem: Brasil. E-mail: maria.abrao@santoandre.org.br

Horizonte, Belo Horizonte, v. 14, n. 43, p. 1039-1063, jul./set. 2016 - ISSN 2175-5841 


\section{Introdução}

Com o passar do tempo, a teologia cristã, na sua tarefa hermenêutica, inova, avança, purifica conceituações, abre novos horizontes de reflexão. Pensa a revelação em Jesus Cristo no coração das mais genuínas interrogações humanas e à luz dos mais diversos contextos. O seu diálogo com outras ciências - chamado a estar sempre em processo - não cessa de manifestar a fecundidade de um encontro purificador em mão dupla: questiona pretensões, revê pressupostos e abre à riqueza que vem de universos distintos ${ }^{1}$.

Tal capacidade de abertura é, indubitavelmente, vital. Ao mesmo tempo, não se deve esquecer que por se gestar e se desenrolar na atmosfera do existir cristão, a teologia está obrigada a pensar essa existência, refletindo sobre tudo o que a configura, o que a desfigura, o que a faz avançar. Nessa tarefa, teologia e experiência espiritual se enriquecem mutuamente mesmo se, historicamente, isso nem sempre tenha se verificado, conforme veremos. Identificar o hiato entre teologia e experiência espiritual cristã está longe de ser uma acareação oriunda da falsa oposição entre teoria e prática. Para além de um atalho - saída simplista - as relações mostram-se mais complexas.

A reflexão propriamente teológica quer compreender o impacto (ou a falta de impacto) recíproco para o revigoramento mútuo, para o reconhecimento, o não estranhamento da linguagem da experiência e da linguagem teológica. O esforço dessa compreensão não é novo, ainda que chamado à contínua renovação. Qual o interesse em pensar hoje as relações entre teologia e experiência espiritual cristã? Qual a pertinência de tal reflexão? Como e sob que condições esse diálogo deve ser conduzido?

\footnotetext{
${ }^{1}$ Neste sentido, a título ilustrativo remetemos, entre numerosos autores, a Paul Valadier, Adolphe Gesché e, em contexto brasileiro, a J.B. Libanio com sua vasta produção, e Mário de França Miranda.
} 
O amálgama imediato entre os conceitos religiosidade e espiritualidade, presta-se a equívocos e oculta desafios ${ }^{2}$. E para tornar mais complexa a questão, lembremo-nos da hipótese há muito anunciada de um século que, para sobreviver, deveria ser místico3. Estamos nesse século? Quais as chances dessa profecia na teologia e na sociedade?

Revisitar como se deram, ao longo do tempo, as relações entre teologia e experiência espiritual cristã, é caminho elucidativo e provocador. Elucidativo por traçar antecedentes comuns aos nossos tempos. Provocador por instigar a prosseguir a análise à luz de novos contextos e desafios. Na verdade, a esperança cristã que se diz na cotidianidade do existir, possui linguagens multiformes que querem expressar a profundidade de um encontro primigênio, nunca terminado. Com contornos inusitados, atravessa o anódino (re)configurando a vida cristã.

Para fundamentar essa reflexão, escolhemos um teólogo do século XX que coloca em relação mundos aparentemente distantes. Hans Urs von Balthasar (1905-1988), o teólogo de Basileia, perfaz um itinerário intelectual surpreendente. No conjunto de sua vasta produção, sua releitura de temas teológicos 4 é feita com rara familiaridade. $\mathrm{Na}$ proposta da obra monumental desse teólogo 5 que não foi professor universitário e recusou-se a fazer carreira universitária, nossa investigação terá como contínuo suporte o Ensaio "Só o amor é digno de fé”6.

Tracemos, pois, a opção aqui feita em três tempos. Num primeiro momento, o recurso a alguns dos grandes santos prepara o diálogo com racionalidades que presidiram a intelecção do mundo e do ser humano, nos grandes períodos do cristianismo, bem como seu influxo na autocompreensão da teologia e da espiritualidade. É nesse contexto marcado por uma oposição crescente que se

\footnotetext{
2 Para maiores precisões semânticas, ver: FIORES; GOFFI, 1993.

${ }^{3} \operatorname{Ver}($ RAHNER, 1969, p.25) e (RAHNER, 2004).

${ }^{4}$ A título ilustrativo, ver sua reflexão sobre o Credo Apostólico: BALTHASAR, Meditaciones sobre el Credo Apostolico, 1991. E, ainda, de modo mais perscrutante e especulativo, o desacordo com Karl Rahner na questão trinitária. Ver HOLZER, 2007.

${ }^{5}$ Para lembrar ao leitor apenas algumas delas nas versões francesas, acompanhadas pelo próprio autor: La gloire et la croix (7 volumes), La Dramatique Divine, La théologie de I'histoire, Raser les bastions etc. Original alemão.

${ }^{6}$ Adotamos a tradução francesa, revista pelo próprio autor. BALTHASAR, 1966. A tradução para o português desta e de todas as outras obras citadas neste artigo são de nossa responsabilidade.
}

Horizonte, Belo Horizonte, v. 14, n. 43, p. 1039-1063, jul./set. 2016 - ISSN 2175-5841 
justifica a tarefa de um segundo momento: entender a concepção de experiência espiritual no cristianismo passando pelo AT, pelo NT e pelos Padres da Igreja. Poderemos então, no terceiro e último momento, olhar o lugar eclesial dessa experiência que possui alcance comunitário e, ipso facto, redesenha o rosto da Igreja e da sua missão.

\section{Aproximação histórica}

No início de seu ensaio, expondo as orientações teológicas que o presidem, Balthasar apresenta o fio condutor que o perpassa: "prolongar o pensamento dos grandes santos que balizam a tradição teológica: Agostinho, Anselmo, Bernardo, Inácio de Loyola, João da Cruz, Francisco de Sales, Teresa de Lisieux” (Balthasar, 1966, p. 11).

A reflexão encontrará toda a sua amplitude e clarividência na medida em que considerar os santos como partícipes de seu tempo, de um momento eclesial, expressões que surgem no cristianismo em suas diferentes etapas de autocompreensão e de maneira de fazer teologia. Considerar a autocompreensão do cristianismo no decorrer dos tempos é fundamental para verificar, a um tempo, o terreno sobre o qual se move a sua teologia, e a qualidade do ar que a faz viver.

Avaliando duas possibilidades de redução do mistério cristão, Balthasar (1966, p. 14) deixa entrever as consequências que desencadeiam. Ele entende que, do período abrangendo os Padres da Igreja até o Renascimento, o cristianismo compreende-se como o que unifica e dá sentido a um mundo fragmentado. É o único princípio de inteligibilidade ao qual todos os outros pretensos princípios devem submeter-se. Tal concepção era sustentada pela identidade entre a filosofia e a teologia e pela livre circulação entre ordem natural e sobrenatural.

O esquema cosmológico, no qual os princípios de unidade do mundo antigo são vistos como "prefigurações do Logos divino", encerra também uma imagem de 
Deus em quem o amor presente no cosmos encontra a sua plenitude e em quem se concentram todas as aspirações de sabedoria. Sabedoria bíblica e sabedoria antiga interpenetram-se e, nos séculos XV e XVI, pode-se falar de "condicionamento recíproco entre evangelismo e humanismo" (BALTHASAR, 1966, p. 16 e 21).

Com o advento da Reforma, em que Lutero derruba a razão aristotélica para dar lugar à fé, abre-se uma divisão entre domínio terreno e domínio espiritual. A ânsia de volta à pureza do evangelho faz com que a filosofia seja recusada como apoio até o ponto de repelir a pergunta pela "credibilidade da Palavra de Deus"7 sob pretexto de mascarar ainda uma justificação racional. No Renascimento, os elementos trazidos pela Reforma serão aprofundados e radicalizados e, pouco a pouco, a imagem predominantemente religiosa e mítica do mundo vai sendo substituída pela religião, pela moral e filosofia naturais.

$\mathrm{O}$ autor reconhece que, nos tempos modernos, o deslocamento do centro de referência do cosmos e da história do mundo para o homem conheceu proporções desafiadoras e comprometedoras para a relação do homem com Deus. O homem começa a entrar em concorrência com o cristianismo. Ele é considerado como o resumo do mundo. Entre o mundo e Deus, o homem é o limite. De microcosmo passa a ser, na ciência da natureza que emerge, “o que constrói a representação do mundo, ultrapassando a própria representação por sua razão”. (BALTHASAR, 1966, p. 35). É assim que, segundo o autor, o ser humano é apresentado por Kant, no final do século das Luzes, levando a redução antropológica ao seu acabamento.

O esquema antropológico, que conhece em sua evolução a passagem pela intersubjetividade, pela relação concreta e dialogal, leva a suprimir o "movimento unilateral e gratuito de Deus em relação ao homem” (BALTHASAR, 1966, p. 96) e insere em seu lugar uma relação bilateral.

\footnotetext{
7 Balthasar lamenta a postura de radicalização de posições dos cristãos diante do desafio que constituía o estatuto da filosofia para a concepção da fé. Evidencia as desastrosas consequências da divisão interna da Igreja para a credibilidade da Palavra e a sutil transformação que vai se operando: a fragmentação da teologia em filosofia e em racionalismo. Cf. Balthasar, 1966, p. 22.
} 
Enquanto a teologia especulativa dos Padres e da Idade Média organizou sob a ordem cosmológica a relação entre Deus e o homem, privilegiando a palavra, a teologia antropológica, característica dos tempos modernos, com seu aparato psicológico e pedagógico, colocou-a gravitando ao redor da existência humana. De tal modo, que tem lugar a pergunta pela possibilidade de uma palavra proveniente de Deus e que seja irredutível ao princípio da subjetividade.

Anterior à passagem obrigatória por esse princípio, o cristianismo conheceu o espaço em que a centralidade da aparição do Amor de Deus foi a fonte e o termo de sua credibilidade.

\subsection{O caminho de unidade entre doutrina e vida}

A caracterização do cristianismo dos primeiros séculos, leva o leitor a assistir à inclusão entre santos e teólogos. É o que Balthasar ressalta explicitando o que entende pelo termo teólogo: "um mestre e doutor dentro da Igreja, cujo ministério e cuja missão consistem em expor a revelação em sua plenitude e totalidade, quer dizer, em considerar a dogmática como o ponto central de seu labor" (BALTHASAR, 1964, p. 235).

Espontaneamente, poder-se-ia excluir a questão da santidade sob o pretexto de que ela integra um plano subjetivo. Contudo, Balthasar a coloca, visando à teologia e aos teólogos, no plano objetivo, deslocando-a das perspectivas ascéticas e morais.

Ler a doutrina na vida. Idealismo de um olhar retrospectivo? O autor quer conduzir à percepção de que se trata, antes, de uma transparência devida a um mergulho na concepção evangélica da verdade que tem como pressuposto não apenas a escuta da Palavra, mas a sua colocação em prática e que, por sua vez, testemunha a veracidade da pregação. Transparência ainda de um enraizamento eclesial, lugar onde é acolhida a missão de ensinar e de tornar conhecida a verdade revelada. 
Inegável, pois, é a influência dessas pessoas nas quais tal missão encontra a ressonância requerida na justa medida para os que as ouviam. Balthasar recorre aos escritos joaninos, mostrando que várias passagens (Jo 7, 18; Jo 8, 32; 1Jo 2, 4.22; 4,2; 2Jo 1, 4; 3Jo 3-4) apontam para a incidência do saber no fazer, para uma verdade que toma corpo (BALTHASAR, 1964, p. 236).

Para ele, resgatar a experiência dessa inclusão, afasta qualquer insinuação de uniformidade dos dons recebidos. Longe disso, está bastante presente em seu pensamento o reconhecimento da ação livre e soberana do Espírito Santo. Presidida pelo respeito desse modo de agir, sua reflexão quer trazer à tona, mais precisamente, deslocar da margem para um lugar de destaque a consonância entre inteligência e vida, fiel “à antiga concepção de doutor que só pode ser a de um santo" (BALTHASAR, 1948, p. 21).

Chamados a sustentar a Igreja em períodos mais ou menos conturbados, essas pessoas renunciam a distanciar-se do cerne da teologia fazendo da dogmática o centro em torno do qual dialogam quer com os adversários, quer com os seus irmãos na fé.

\footnotetext{
"A teologia dos Padres e a da Idade Média era doctrina sacra não só pelo objeto, mas também pela forma. Era doutrina sacra porque nela a dimensão espiritual do mistério objetivo e da iniciação pelo Espírito Santo continuava, presente não só na totalidade, como uma vaga atmosfera, mas em cada um dos passos do pensamento." (BALTHASAR, 1964, p. 273)
}

Habituados como estão a mover-se dentro do clima de unidade, conjugam, não raras vezes, com matizes diferentes, os títulos de doutor, pastor e santo. "Personalidades totais" (BALTHASAR, 1964, p. 237) constituem-se em seguros pontos de referência e testemunham a possibilidade real dessa harmonia. A evidência de que nem todos a concretizaram não pode autorizar o desvio e nem dispensa o reconhecimento dessa síntese nas personalidades mais significativas, tais como Irineu, Cipriano, Atanásio, os dois Cirilos, Basílio, Gregório Nazianzeno, Gregório de Nissa, Epifânio, Teodoro de Mopsuéstia, Crisóstomo, Teodoreto, Hilário, Ambrósio, Agostinho, Fulgêncio, Isidoro. 
Contudo, o quadro descrito, abrangendo até o início da Alta Escolástica, começa a sofrer alterações. Os acréscimos ou as ausências verificadas levam Balthasar a esboçar um outro perfil.

\subsection{Progressiva dissociação entre teologia dogmática e teologia espiritual}

Se os primeiros séculos puderam conhecer em uma mesma pessoa a simultaneidade dos títulos de grandes santos e grandes teólogos, a partir do século XIII, essa situação sofre, na visão do autor, um esfriamento e não possui mais a mesma proporção. Que elementos teriam entrado em jogo para compor o quadro delineando uma possível dissociação?

Sobretudo dois parecem destacar-se. O primeiro é o que concerne a uma gradual "escolarização" (BALTHASAR, 1964, p. 239) da teologia, acrescida da paulatina recepção do aristotelismo. Não foi sem grandes desafios que os cristãos encararam a nova situação, a qual vinha acompanhada de um clima de exaltação diante do instrumental científico que lhes era apresentado. Além de colaborar para um embasamento da teologia, o aristotelismo do século XIII sinaliza o início da devida independência das ciências, tanto as da natureza, como as do espírito.

O segundo elemento, ligado ao primeiro, diz respeito ao lugar da filosofia nessa constelação. Configurando sua autonomia, ela passa consequentemente a elaborar o seu conceito sobre a verdade: Adaequatio intellectus ad rem. Tal elaboração - desconhecendo o conceito de verdade na perspectiva trinitária - é justificada e atribuída por Balthasar (1964, p. 240) ao estatuto que é próprio à filosofia.

Que vínculos foram desenvolvidos entre a teologia e a filosofia nesse panorama? Balthasar (1964, p. 241) mostra que as tentativas de adaptação da teologia sob a forma de transposição de conceitos supunham um trabalho extremamente exigente e que, na teologia pós-escolástica se viu votado ao fracasso. 
Sua reflexão leva-nos a reconhecer uma agravante no ensino tal como era praticado. Ele colabora para reforçar a primazia dos conceitos filosóficos condicionando-lhes e submetendo-lhes a aproximação teológica.

A separação parece desconsiderar que a articulação própria da vivência das virtudes teologais supõe a pertença ao conteúdo de uma dogmática (BALTHASAR, 1964, p. 71).

\subsection{Consequências da consolidação da ruptura}

Resistência ou fuga? A busca de outro caminho é vista pelo autor como uma necessidade que se apresenta aos que o estudo da filosofia e da teologia parecia requerer um esforço titânico, mesmo considerando os que possuíam capacidade especulativa.

As alternativas que se delineiam não parecem ser nem satisfatórias, nem fáceis. Reforçar o paralelismo procurando manter a piedade malgrado os estudos ou tentar conciliar a missão que acreditavam ter recebido de Deus com partes do aparato escolástico, como é o caso, evoca Balthasar (1964, p. 246), de "Teotimo" (Francisco de Sales) e da "Subida do Monte Carmelo" (João da Cruz). Teria ignorado que ambos trazem os títulos de doutores da Igreja? Não, mas explicita o que os coloca na contramão da experiência dos antigos: a passagem de uma mística objetiva e inteiramente orientada para uma percepção mais aguda do conteúdo da Revelação, para uma mística subjetiva que faz sobressair as experiências interiores e os estados, colocando entre parênteses a dogmática.

Mostra ainda que essa via foi aberta através de uma outra ciência que se erigiu paulatinamente paralela à dogmática. O ônus, demasiadamente grande, provoca a evasão das pessoas espirituais do campo da teologia. A "ciência da vida cristã”, que com a Devotio Moderna adquirirá sua autonomia, passará a ser o porto seguro a abrigar os náufragos que sucumbiram sob o peso da imposição filosófica. 
Observa que nessas circunstâncias, opera-se um empobrecimento, fruto de uma exclusão recíproca. Por um lado, os que se lançam no caminho da dogmática evitam o diálogo que não apenas integraria a experiência espiritual, mas também revigoraria a reflexão dogmática. Tacitamente, a santidade parece considerada como aquela que contamina com sua piedade a pureza da ciência e, portanto, para o bem e para a preservação da própria teologia, convém não ser santo a fim de não misturar os níveis (SICARI, 1991, p. 255).

Por outro lado, apresenta-nos o exílio dos santos que enveredam rumo à predominância da subjetividade e à acentuação da experiência em detrimento de Deus. Abstêm-se do que poderia levá-los a comentar a Revelação porque, sentindose inaptos para fazê-lo, entregam essa tarefa aos especialistas. Assim procedendo, tornam-se corresponsáveis pela fragmentação que compromete a compreensão de Cristo e de sua imagem.

A theologia spiritualis ou mystica, que até o século XII compreende a dimensão objetiva do mistério, conhece, com os espanhóis que deram relevância à experiência humana e subjetiva do mistério, alteração no conceito de mística. O conceito recebe o acréscimo do adjetivo "ascética" denotando, respectivamente os aspectos passivo e ativo que ele abarca. A importância atribuída ao pragmático e ao psicológico desembocam, principalmente no século XIX, num distanciamento e numa perda do centro da Revelação. Sujeito psicológico e dogmática estranham-se mutuamente por desconhecerem seu centro unificador.

O rosto subjetivo da dogmática e o rosto objetivo da espiritualidade, tomando estradas independentes, se desfiguram. Passando cada qual a girar em torno de si mesmo, obrigam os cristãos à identificação que trai a totalidade do mistério. 


\section{A experiência espiritual}

\subsection{Concepção e possibilidade}

Deus e seu amor pela humanidade não podem simplesmente ser colocados como uma realidade ao lado de tantas outras. Em virtude de seu caráter absolutamente único, Deus não pode ser dominado pelos sentidos e pelo espírito humanos. Contudo, se ele quer dar-se a conhecer, e se a plena realização humana supõe um encontro livre e pessoal com o Criador, não haveria uma contradição interna, posto que é impossível ao homem alcançá-lo?

Querendo manifestar-se, Deus cria as condições para que o homem possa reconhecê-lo apesar da singularidade desta relação e em sua própria singularidade (BALTHASAR, 1966, p.93). Dá-lhe as condições, ao criá-lo com a capacidade radical para escutar a sua Palavra. Dom inalienável que só a liberdade humana pode consentir em obscurecer sem, contudo, ser capaz de anulá-lo.

À luz da analogia do amor de uma mãe que se manifesta dia após dia, acabando por despertar o amor de seu filho, Balthasar situa a manifestação de Deus ao homem. Igualmente, o amor de Deus que cavou o coração humano faz com que este ser, à luz do amor recebido encontre o Amor.

Envolvendo uma realidade tão distinta das que habitualmente são conhecidas, pode-se, legitimamente, empregar o termo experiência? Balthasar (1965, p. 185) considera indispensável o conceito de experiência, embora reconhecendo os preconceitos que carrega ao longo da história da teologia. Indispensável, porque o encontro com Deus exige nada menos que o homem todo. Introduzir o termo experiência permite, segundo ele, assegurar que não apenas a razão, mas ainda a vontade, a alma, o corpo participem e não sejam excluídos dessa relação. 
A experiência espiritual cristã, tal como ele a concebe, não se refere a um estado particular. Não é tampouco uma elevação ao absoluto, prescindindo da trama de relações da história e do mundo.

No seu entender, ela coincide com a experiência de fé que, precisamente por seu caráter não palpável, acontece graças a uma mediação e que, ao invés de reenviar o homem a si mesmo, aos seus recursos interiores, provoca a saída de si para remetê-lo à existência de Cristo.

Dentre as condições de possibilidade da irrupção do amor de Deus na história humana e precedendo o encontro do homem particular com o amor de Deus, Balthasar situa um encontro arquetípico que reconhece e acolhe a unilateralidade desse amor. Nele, Deus mantém a iniciativa e suscita uma resposta da qual depende a encarnação do Filho. Iniciativa de Deus e resposta humana compõem os relatos da experiência histórica dessa relação.

\subsection{Acepção}

\subsubsection{No Antigo Testamento}

A concepção de experiência no AT é analisada sob dois pontos de vista: o do sujeito da experiência e o do seu alcance e função.

Sob o prisma do sujeito da experiência, observa-se ao longo de todo o AT que Deus é quem busca e quem quer encontrar o ser humano. Sua aproximação é, em geral, inesperada e desnorteante. Supera o que se poderia conceber, como tão bem o ilustram os relatos das vidas dos patriarcas e dos profetas.

Seria um equívoco julgar que tal experiência abra parênteses e preserve o homem bíblico das adversidades. Em direção diametralmente oposta a esse modo de pensar, prossegue o pensamento de Balthasar fiel ao dado bíblico. Será justamente em meio às vicissitudes que tais homens comprovarão a veracidade de 
sua adesão, a autenticidade de sua resposta. Mostra que tais situações, longe de serem fortuitas, são colocadas, segundo a concepção bíblica, em relação com a vontade de Deus. Porque, na perspectiva dessa concepção, é Deus quem quer fazer uma experiência. Experiência que perpassa toda a história da salvação: verificar se o seu eleito realiza a sua missão segundo o que lhe fora apontado.

Suportar a inversão dos papéis e deixar que Deus o experimente é o grande desafio do homem do AT. Aliás, observa Balthasar (1980, p. 52), não é a recusa a este desafio que constitui o pecado dos pais, no deserto?

Seguindo a orientação de sua reflexão, o foco é deslocado do homem para Deus. A este último cabe a iniciativa do encontro, a ele cabe definir o seu modo e a ele é reservada a prerrogativa de experimentar o homem, colocando-o à prova.

A experiência que o homem faz de Deus acontece indiretamente: na aquiescência ou na recusa a Deus que o interpela. Deus projeta sobre o homem uma centelha de sua alegria por tê-lo encontrado perseverante nos seus caminhos. E essa centelha constitui a experiência humana de Deus que traz ainda como marca distintiva a renúncia que a fé comporta: obediência ao caminho de Deus e recusa em dar-se as próprias leis, mesmo em meio às tentações, sejam elas internas ou externas.

O segundo ponto de vista concerne ao alcance e à função dessa experiência. A experiência de Deus no AT é lida por Balthasar (1965, p. 279) em uma perspectiva que tem em vista a encarnação do Verbo de Deus. Ela prepara a humanidade para o encontro com Deus feito homem.

Observa que o encontro com Deus, para o homem bíblico, implica igualmente sua razão, seu espírito, sua sensibilidade, sua alma, seu corpo. Deus que o procura e vem ao seu encontro quer dirigir-se à totalidade de sua pessoa. E, dado que a interpelação suscita uma resposta, é, igualmente, com todo o seu ser que o homem é chamado a comprometer-se. Afinal, não se trata de uma aproximação no 
âmbito ontológico, mas de um conhecimento vital: "Conhecer Deus tem, pois, a urgência e a intimidade a um tempo espirituais e corporais da relação entre o homem e a mulher" (BALTHASAR, 1965, p. 219).

A revelação de Deus que se dá para o homem respeita a realidade que lhe é peculiar: a de não ser "puramente espiritual”. Descartar como infantilismo religioso o caráter sensível que marca os encontros com Deus no AT seria desconsiderar que, para o homem bíblico, todas as esferas são ou podem ser o lugar de expressão e o domínio da ação do Deus vivo.

Qualificando de encontros arquetípicos as teofanias e sem ignorar a dificuldade muitas vezes encontrada em delimitar claramente o divisor de águas entre a experiência do vidente e o revestimento literário, Balthasar afirma a presença concreta de Deus diante de quem o homem pressente, na própria manifestação grandiosa e sensível, Deus sempre maior.

Dois aspectos interligados merecem ainda ser evidenciados nas experiências de Deus no AT. As revelações delas provenientes não eram apenas individuais primeiro aspecto -, mas se alargavam a um povo, ainda que representado por algumas testemunhas (BALTHASAR, 1965, p. 281).

$\mathrm{O}$ segundo aspecto diz respeito à sua função eclesial. O foco permanece sobre o que é mostrado. Não é o sujeito da experiência que ocupa o primeiro plano, mas a própria revelação.

Mesmo as grandes teofanias aos profetas, longe de se constituírem em patrimônio particular, concernem de tal modo a todo o povo que são normativas para Israel (BALTHASAR, 1965, p. 283). Ao invés de separarem da comunidade de fé, as experiências de Deus no AT inserem-se no seu centro, investindo o homem de uma missão e função e estreitando os laços da Aliança de Deus com o seu povo. 


\subsubsection{No Novo Testamento}

A experiência de Deus no NT, Balthasar a organiza sob dois ângulos: o das testemunhas oculares e o de Jesus. No centro, dispõe o mistério da encarnação que é o crivo pelo qual devem passar todas as experiências anteriores, contemporâneas e posteriores à vinda do Verbo que se fez carne.

Todos, testemunhas oculares e as gerações que se sucederam, são chamados à mesma experiência de fé que comporta a experiência fundante do Filho: "experiência de renúncia, de obediência, de sofrimento" (BALTHASAR, 1965, p. 220). Em Jesus, teofania de Deus, os homens fazem a experiência sensível e objetiva de Deus. Reconhecem que, ao entrar na via de seu seguimento e para assumir a forma crística, são igualmente chamados à experiência do sofrimento que é o lugar de aprendizagem para o conhecimento de Deus e um modo de participação na própria experiência de Cristo.

O caminho da percepção e do reconhecimento humano que passa pelos sentidos permite que, pela livre disposição divina e contradizendo todas as tentativas de espiritualização, Deus em Jesus toque o homem e o homem toque Deus.

As experiências que homens e mulheres fazem, entre outras, da Ressurreição de Jesus testemunham que o elemento sensível não é excluído da objetividade da fé. Balthasar (1965, p. 265) critica a paulatina espiritualização das teofanias que, no judaísmo tardio, não reserva nem aos anjos em posição mais elevada a visão de Deus. Critica igualmente o influxo do pensamento alexandrino que tende a transpor para o campo do espírito o que é corporal na história de Deus com o seu povo, relegando-o ao mundo simbólico. Na concepção dessa vertente sob o peso da visão platônica, a passagem da Antiga para a Nova Aliança representa igualmente a passagem, a libertação, a purificação do sensível para a verdade espiritual. O cristianismo ocidental não atravessou incólume as águas que desembocaram, não 
raras vezes, em um desprezo da encarnação e que deram uma interpretação considerada abusiva das palavras ao apóstolo Tomé.

Tanto no AT como no NT a aproximação de Deus deixa uma marca indelével naquele que, gratuitamente, foi favorecido por este contato. Não é ele o que determina a sua natureza, duração, ou as circunstâncias nas quais ela se desenrola. Ao tomarmos a experiência dos apóstolos, verificamos que somente pela livre iniciativa e deliberação de Jesus eles se tornam partícipes de acontecimentos teofânicos. Da parte humana, ausência total de manipulação; da parte divina, manifestação da radical liberdade do amor desinteressado selando o encontro. Mas esse traço de Deus, mais do que uma marca subjetiva - posto que, como ficou acima salientado, não são as disposições subjetivas que são visadas - é portador de um anúncio que só é reconhecido eclesialmente mediante as provas que o acompanham.

Distanciando-se da complexidade das visões peculiares às religiões mistéricas, a manifestação divina vem, para eles, despojada, clara, sóbria, inteligível - algumas das provas de que a experiência é genuína - e trazem em si o anúncio da dimensão escatológica.

O segundo ângulo, o da experiência de Deus feita por Jesus é tomado em seu duplo aspecto. Por um lado, assumindo plenamente a existência humana, permite que Deus o experimente ${ }^{8}$. Por outro lado, sua pessoa e sua missão situam sua experiência de Deus em um plano inteiramente distinto das experiências que os outros homens fazem de Deus, tal como o atestam particularmente os escritos joaninos.

\footnotetext{
${ }^{8}$ Uma vez mais, Balthasar faz o paralelo entre a insubmissão dos pais no deserto "... como no dia de Massa, no deserto, quando vossos pais me provocaram e tentaram, mesmo vendo as minhas obras" (SI 95,8-9) e a atitude constante de Jesus recusando todas as formas de messianismo terreno, mas de forma programática no episódio das tentações: "Não tentarás ao Senhor teu Deus". Cf. BALTHASAR, Nouveaux points de repère, 1980, p. 52.
} 


\subsubsection{Nos Padres}

Diversas terminologias entrecruzam-se na leitura que Balthasar faz da experiência em Irineu, Orígenes, Evágrio Pôntico, Macário, Diadoco e Máximo, o Confessor9.

Nosso objetivo não é o da comparação sistemática entre eles, nem o da busca da uniformidade dos termos ou de suas equivalências, mas sim o de, localizando-os nas respectivas leituras, favorecer sua intelecção, registrar sua importância e permitir que sua luz própria contribua para a leitura do conjunto da experiência espiritual.

Balthasar aponta a experiência ocupando o centro da teologia de Irineu, e Cristo como a única condição de possibilidade da vida em Deus. Para este Padre, a experiência fundamental é a do distanciamento de Deus porque esta fortalece o homem para uma nova experiência de aproximação. Através da experiência do bem, definido por Irineu como “obediência a Deus, fé e observância dos mandamentos", e do mal, definido como o seu oposto, o homem faz a experiência de Deus. É exatamente pela experiência dos contrários - com a integração progressiva do que experimenta -, que o homem é levado a optar pela obediência. A última de suas experiências é a morte. Passando por ela e verificando o alcance de sua libertação, faz igualmente a experiência do amor que lhe fora reservado e de um constante reconhecimento diante de Deus. Contudo, mostra que a única condição de possibilidade da experiência da vida em Deus é, para Irineu, Cristo.

Em Orígenes, em quem o foco de interesse deixa pouco espaço para uma teologia da experiência, Balthasar (1980, p. 55) lê a construção de uma base neoplatônica para a experiência espiritual do afastamento de Deus. Ela é vista como um tédio sofrido pelo espírito que se encontrava unido a Deus antes que o

\footnotetext{
${ }^{9}$ Para uma aproximação do tema, ver: BALTHASAR, 1947. Para além de Balthasar, ver ainda: CLÉMENT, 2003.
} 
mundo fosse. Mas a Providência acompanha o homem em seus descaminhos, aguardando pacientemente o momento de uma intervenção.

A negação do sensível é, para Evágrio Pôntico, a condição para se chegar a um sentido espiritual. É a posição à qual o espírito afastado de Deus deve anelar, exercendo-se, com esta finalidade, no despojamento do sensível. Dentro de sua concepção, a ausência de sentimento é o mais alto nível de oração (BALTHASAR, 1965, p. 225).

Na perspectiva de confronto com o messalianismo, Macário explicita a sua compreensão da experiência mística afirmando a necessidade de um contínuo combate que implica a oração e a mortificação, pois fazer a experiência do Espírito não assegura uma consolidação que isenta da queda na concupiscência. No batismo, recebe-se a graça que é apenas o começo de outras experiências de graça na qual Deus se faz sentir. Se, por um lado, Macário dá grande importância ao combate, à perseverança, por outro faz notar que não há nenhuma relação entre o esforço humano e a experiência em que Deus é sentido. É a pedagogia de Deus que dirigirá a prevalência da consolação ou da desolação.

Considerada como o "caminho para o perfeito amor e para a visão experiencial de Deus", a experiência de Deus em Diadoco, supõe um homem em quem o Espírito de Deus ocupa o mais profundo de seu ser. No homem assim compreendido, tudo o que se opõe a Deus permanece na superfície. Malgrado a dualidade presente no homem por causa da queda original, o homem recebe algo do sentir de Deus que o fortalece no início de sua vida espiritual. Sua doutrina sobre o discernimento dos espíritos permite um conhecimento experiencial do espírito de Deus e do espírito do demônio (consolações e desolações), um conhecimento do próprio homem e um conhecimento do agir de Deus em relação ao homem. Para ele, a experiência espiritual conhece um crescendo que vai de um vago sentimento da presença, passando por dificuldades e por noites que a purificarão, a uma experiência espiritual profunda. 
Para Máximo, a dimensão experiencial reside em uma fé consequente, o que significa que a fé só é real se vem acompanhada da ação e do amor. Do contrário, é apenas uma aparência. Aquele que observa os mandamentos, acolhe Cristo - que consigo traz todas as suas riquezas -, nele permanece e dele recebe a vida. Apesar de entender que o desapego dos bens terrestres e que o fim do ódio conduzem à visão de Deus, Máximo destaca, antes, a tendência do espírito a voltar para a sua origem transcendente e designa a experiência mística como a tomada de consciência de que o espírito é transcendente e se lança em direção ao Deus que não podemos conhecer.

\section{Experiência espiritual e santidade: seu lugar na vida da Igreja}

No apagamento dos santos, lembra o autor, encontra o homem a orientação para o amor. Amor cristão, digno de fé, a que são orientados os pecadores pelos próprios santos. Na abissal diferença entre o amor absoluto e os que a ele se remetem por seu amor, "o amor anunciado pela revelação bíblica não seria mais digno de fé" (BALTHASAR, 1966, p. 155) se fosse obscurecido por uma identidade, por uma "teologia pietista ou mística ou espiritual joaquimita" (BALTHASAR, 1966, p. 154). Nisso, o que é especificamente cristão apagar-se-ia em benefício do humano. Se assim fosse, o amor dos santos estaria resumido à sua personalidade religiosa e buscar-se-ia a honra própria. A maior glória de Deus é o ideal para os verdadeiros santos. A glória do amor de Deus sempre foi o único critério para as suas ações, portanto, nelas não reconhecendo a busca da própria glória. Eles estão escondidos e imersos em Deus que é o único centro de suas vidas. A relação com Deus é uma relação de liberdade em que o indivíduo torna-se mais livre em si mesmo e para si mesmo, à medida que se torna livre somente para Deus.

É somente pelo próprio sacrifício de Deus que se pode compreendê-lo como sendo ele mesmo amor. E foi à luz desse amor que os santos situaram a sua existência e tornaram-se incompreensíveis fora desse prisma. 
Pelos santos, há possibilidade do reconhecimento do ser autêntico e essencial da Igreja. Sem acreditar no amor de Deus, o enigma continua indecifrável e o ser da Igreja, obscuro. Nesse ângulo, tudo permanece incompreensível e contraditório.

Apoiando-se na palavra de Paulo aos efésios (Ef 2,20), Balthasar (1955, p.9) afirma que a Igreja é fundada sobre os ministérios e os carismas, sendo que estes são considerados tanto em sua dimensão objetiva como subjetiva e, desse modo, tanto em sua santidade objetiva como subjetiva. Ter recebido a promessa de uma santidade objetiva não exime a Igreja da santidade subjetiva, vivida pessoalmente. E a finalidade do que é institucional é levar a esta santidade.

A santidade subjetiva, que na Igreja encontra a possibilidade de realização, abre ao amor preferencial de Deus e dos homens, vive para a comunidade da Igreja, está em constante processo de descentramento e recebe de Deus, inclusive o modo como vai se doar, não se autodeterminando nem em seu modo de doação. Pois é o Espírito que distribui, para a edificação da Igreja, os ministérios e os carismas.

A missão recebida comporta a forma de santidade que é, a um tempo, já dada e sempre pedida. Dessa missão-santidade deriva o lugar único a ocupar no Corpo da Igreja, lugar que é discernido na oração e na meditação.

Deus considera e dá a liberdade para que o homem cumpra a Sua vontade, em nada suprimindo o que é próprio do homem. Considera igualmente sua natureza, suas capacidades, suas possibilidades. Daí poder se afirmar, segundo Balthasar, que o santo é aquele que se torna mais ele mesmo. No entanto, nada nesse conjunto que o constitui permite deduzir a que visa a graça de Deus.

Além da diversidade das vocações, há diferenças na vocação à santidade: a santidade ordinária à qual todos os cristãos são chamados e a santidade diferenciada na qual Deus faz sobressair uma pessoa como modelo para o bem da Igreja. Paulo constitui um destes exemplos. E todos os que, pela renúncia 
evangélica, do mesmo modo a ela são chamados, compreendem que estão obedecendo ao Espírito.

Há, contudo, no decorrer da história da Igreja, os que se atribuem a si mesmos o chamado a uma “missão especial de santidade” e que, por isso mesmo, pelo esforço que realizam, deixam transparecer a não autenticidade da fonte. Mas a missão especial da santidade é um dom e aqueles aos quais Deus a atribui são todos obedientes.

Afora a distinção entre santidade “ordinária” e santidade "representativa”, Balthasar (1955, p. 15) distingue todos os caminhos que vão da cabeça para o corpo, - que são os que irrompem na Igreja e manifestam um desígnio claro de Deus sobre sua Igreja. Distingue, ainda, os que vão do corpo para a cabeça, - que incluem missões que surgem no seio da Igreja, da comunidade, das ordens religiosas - e que se transformam em modelo. Ambos os caminhos são eclesiais, mas julga ser melhor o primeiro, caracterizado por sua clareza e irrefutabilidade.

A canonização dos do primeiro grupo é um ato de obediência da Igreja ao seu Senhor, enquanto que a dos do segundo manifesta, antes, o desejo da Igreja ouvido pelo Senhor. Por essa razão, a Igreja deve estar muito atenta para descobrir os santos que Deus lhe envia.

São os do primeiro grupo os mais admirados pelo povo cristão. Ainda que sejam os menos imitáveis, são reconhecidos como uma nova maneira oferecida para imitar Cristo e para praticar o Evangelho:

Para os teólogos, ao contrário, representam antes uma nova exegese da revelação, um enriquecimento da doutrina por novos traços até então pouco notados. Mesmo se eles próprios não são teólogos ou sábios, toda a sua existência é um fenômeno teológico, que contém uma doutrina viva, dada pelo Espírito Santo e, consequentemente, muito digna de atenção, atual e fecunda ao lado da qual - uma vez que é dirigida a toda a Igreja ninguém pode passar sem dar atenção (BALTHASAR, 1955, p. 17). 
Representando a tradição eclesial viva, os santos apresentam uma interpretação dinâmica da revelação de Cristo. Uma das objeções, segundo o autor, poderia ser a de que a Bíblia é suficiente, mas ela não se sustenta se pensarmos que Deus pode dar, através de exemplos concretos, a amplidão de sua Palavra. Ele é livre para continuar a fazê-la ecoar do modo como achar conveniente e por meios considerados muitas vezes ineficazes.

A interação real entre teologia escolar e teologia dos santos deve ser pressuposta nesse caminho apontado por Balthasar. Para prejuízo mútuo, teologia e santidade na época moderna separaram-se. De um modo geral, a hagiografia moderna colabora para essa separação ao apresentar a existência dos santos servindo-se apenas de categorias históricas e psicológicas, procedimento este que contribuiu grandemente para o obscurecimento de sua missão teológica.

No grande santo, não se trata de procurar qualidades heroicas ou pessoais. Brilha nele a vida entregue para a missão, malgrado sua consciência da disparidade entre seu serviço efetivo e a missão que lhe é confiada. E é exatamente procurando enxergar sua missão e o que, através dela, Deus quer dizer à Igreja que poderia ser ultrapassado o horizonte subjetivo da vida dos santos o qual, embora sendo importante, não encerra o essencial de sua missão.

\section{Considerações conclusivas: à escuta da teologia}

Ao termo de nosso percurso, voltemo-nos para a afirmação proposta por Balthasar (1966, p. 11) no início, explicitando o seu intuito: "prolongar o pensamento dos grandes santos que balizam a tradição teológica...” Surpreendentemente, faz a escolha da expressão ‘tradição teológica' e não 'tradição espiritual'. O leitor atento terá percebido, ao longo do caminho, elementos capazes de indicar o porquê dessa opção. 
Se quisermos hoje compreender como as relações entre teologia e experiência espiritual no cristianismo se apresentam, não podemos evadir-nos de olhar a origem histórica da oposição conflituosa esboçada.

Terá a Teologia contemporânea superado o conflito evocado? Terá a experiência espiritual cristã integrado a teologia? Convicta de sua tarefa de ocuparse da inteligibilidade da fé e de sua articulação e apresentação sistemática, a teologia vê-se desafiada ao exercício contínuo de acolher "necessariamente a estrutura de seu objeto e princípio - a fé" sem negligenciar nenhum de "seus três componentes principais: experiência, inteligência e prática” (BOFF C., 2012, p. 29).

Na contemplação dos santos, a experiência espiritual cristã discerne a teologia num novo modo de existir. Ela não os considera como homens extraordinários, com virtudes levadas ao heroísmo. Enfatiza que, conscientes eles mesmos da fragilidade de sua adesão a Cristo, hauriam forças nesse centro do qual nunca se apartavam. São, antes, "ilustrações da realidade íntima de Cristo" (BALTHASAR, 1964, p. 262).

Balthasar empenha-se em mostrar a preocupação desses homens em não se afastar da origem, da fonte de onde jorra a vida, a Palavra de Deus enviada ao mundo.

A realidade íntima dessa Palavra manifesta-se ao homem na figura de Jesus, tal como ele se apresentou à humanidade. Dessa apresentação depende verificar quem é Jesus e quem é o seu seguidor. Não é possível deduzir a priori quem é ele, somente através da sua vida, do recurso ao que ele fez, viveu, disse de si mesmo, de seu Pai, da humanidade.

Havendo interdependência entre a teologia vivida e a teologia dogmática, caberá, num trabalho ulterior, verificar mais de perto as raízes que trazem a seiva para essa existência teológica. Por ora, restringimo-nos a apresentar apenas um 
aspecto do retrato herdado da reflexão desse grande teólogo, cuja vida e vigoroso trabalho intelectual buscavam equacionar Teologia e Santidade.

\section{REFERÊNCIAS}

BOFF, C. Teoria do Método Teológico. 5. ed. Petrópolis: Vozes, 2012.

CLÉMENT, Olivier. Fontes: Os Místicos Cristãos dos Primeiros Séculos, Textos e Comentários. Juiz de Fora: Subiaco, 2003.

FIORES, S.; GOFFI, T. Dicionário de Espiritualidade. São Paulo: Paulus, 1993.

HOLZER, Vincent. Le Dieu Trinité dans l'histoire. Le différend théologique Balthasar-Rahner. Paris: Cerf, 2007.

RAHNER, Karl. Escritos de Teología VII. Madrid: Taurus Ediciones, 1969.

RAHNER, Karl. O Cristão do Futuro. São Paulo: Fonte, 2004.

SICARI, A. Hans Urs von Balthasar. Teologia e santità. In: LEHMANN, K.; KASPER, W. Hans Urs von Balthasar; Figura e Opera. Casale Monferrato: Piemme, 1991.

VON BALTHASAR, Hans Urs. L'amour seul est digne de foi. Paris: Aubier-Montaigne, 1966.

VON BALTHASAR, Hans Urs. Ensayos Teologicos I, Verbum Caro. Madrid, Guadarrama: Cristiandad, 1964. Tradução de Andrés Pedro Sánchez Pascual. Original alemão.

VON BALTHASAR, Hans Urs. Théologie et Sainteté. In: Dieu Vivant., Paris: Seuil, n.12, oct-déc, 1948.

VON BALTHASAR, Hans Urs. Nouveaux points de repère. Paris: Communio Fayard, 1980.

VON BALTHASAR, Hans Urs. La gloire et la croix. Les aspects esthétiques de la révélation I. Apparition. Paris: Aubier, 1965.

VON BALTHASAR, Hans Urs. La gloire et la croix. Les aspects esthétiques de la révélation II. Styles. D’Irenée à Dante, v.1. Paris: Aubier, 1972.

VON BALTHASAR, Hans Urs. La gloire et la croix. Les aspects esthétiques de la révélation II. Styles. De Jean de la Croix à Péguy, v.2. Paris: Aubier, 1972.

VON BALTHASAR, Hans Urs. La gloire et la croix. Les aspects esthétiques de la révélation III. Théologie. L’Ancienne Alliance, v.1. Paris: Aubier, 1974. 
VON BALTHASAR, Hans Urs. La gloire et la croix. Les aspects esthétiques de la révélation III. Théologie. La Nouvelle Alliance, v.2. Paris: Aubier, 1975.

VON BALTHASAR, Hans Urs. La gloire et la croix. Le domaine de la métaphysique, v. 1. Les fondations IV. Paris: Aubier-Montaigne, 1981.

VON BALTHASAR, Hans Urs. La gloire et la croix. Le domaine de la métaphysique, v. 2. Les constructions IV. Paris: Aubier-Montaigne, 1982.

VON BALTHASAR, Hans Urs. La gloire et la croix. Le domaine de la métaphysique, v. 3. Les fondations IV. Paris: Aubier-Montaigne, 1983.

VON BALTHASAR, Hans Urs. Maxime, le confesseur. Paris: Aubier-Montaigne, 1947.

VON BALTHASAR, Hans Urs. Meditaciones sobre el Credo Apostolico. Salamanca: Sígueme, 1991.

VON BALTHASAR, Hans Urs. La prière contemplative. Bruges: Desclée de Brouwer, 1959 .

VON BALTHASAR, Hans Urs. La Théologie de l'histoire. 6. ed. Paris: Plon, 1955.

VON BALTHASAR, Hans Urs. Dieu et l'homme aujourd'hui. Paris: Desclée de Brouwer, 1958. 